\title{
How Canada Compares: Engagement of Seniors in Chronic Condition Management in 11 Countries
}

\author{
Grace Cheung, Patricia Sidhom and Katerina Gapanenko
}

\begin{abstract}
Patient engagement is a growing movement that emphasizes the collaboration between patients and their healthcare providers. Patient engagement in chronic condition management is important because its success relies on patients preventing and acting on symptoms outside of their doctor's office. For many chronic conditions, seniors are often affected more than other age groups. Here we highlight how Canadian seniors are engaged in their management of chronic conditions compared to seniors in $\mathbf{1 0}$ peer countries. Although more Canadian seniors reported feeling engaged by their regular doctors than the international average, there is room for improvement.
\end{abstract}

\section{Introduction}

Patient engagement is an initiative that emphasizes active collaboration between patients, families and healthcare providers. By working with their healthcare providers, patients can gain knowledge and skills to act on health information and to participate in the decision-making process for their care (Coulter 2012). There are many ways to engage patients in their care, such as health coaching, patient decision aids and self-management education (Coulter 2012). In particular, self-management education can improve health outcomes for patients with chronic conditions (Simmons et al. 2014).

The goals of chronic condition management are to prevent complications and the onset of additional conditions and to treat the existing conditions. These goals can be achieved when patients adopt healthy lifestyles, take medications regularly and monitor their own health (Bodenheimer et al. 2002). Patient engagement can help facilitate these activities by helping patients to understand their importance and to develop the skills and confidence they need to take action (Simmons et al. 2014).

Chronic conditions are currently the leading cause of death in the world (WHO 2017). Adults with multiple chronic conditions use more healthcare services and cost the health system more (Anderson 2010). Because the chance of developing chronic conditions increases with age, chronic conditions affect more seniors than other age groups. In this article, we describe how Canadian seniors are engaged in their chronic condition management compared to seniors in other countries based on a report from the Canadian Institute for Health Information: How Canada Compares: Results from The Commonwealth Fund's 2017 International Health Policy Survey of Seniors (CIHI 2018).

\section{Data Source and Analysis}

The Commonwealth Fund's (CMWF) 2017 International Health Policy Survey interviewed seniors aged 65 and older in 11 countries: Australia, Canada, France, Germany, the Netherlands, New Zealand, Norway, Sweden, Switzerland, the United Kingdom and the United States. In Canada, 4,549 seniors responded to the survey; the overall response rate was $23.2 \%$. Survey data for Canada were first weighted by age, gender and educational attainment within each of the 10 provinces. Data were subsequently weighted for knowledge of official languages within Quebec and Canada as a whole. Finally, data were weighted to reflect Canada's overall geographic distribution by province and territory. Owing to small sample sizes, detailed territorial results are not shown. Statistical testing was performed to determine whether Canadian and provincial results were significantly different from the international average of 11 countries.

\section{More Canadian Seniors Felt Engaged by Their Regular Doctors than the International Average} For patients to develop the knowledge, skills and confidence they need to manage their own conditions, they need to be provided with the relevant information. This depends on healthcare providers spending time with their patients, encouraging patients to ask questions, clarifying any confusion and explaining things in ways that patients can understand. By gaining the relevant knowledge, patients can participate in decision making for their treatment or care with their healthcare providers. In Canada, more seniors than the international average felt their regular doctor or medical staff "always" fostered an environment that allows patients to develop health literacy and participate in decision making (Table 1). 
TABLE 1.

Percentage of respondents who said that their regular doctor or medical staff "always" engaged them in specific ways

\begin{tabular}{|c|c|c|c|c|c|c|c|c|c|c|c|c|}
\hline & $\begin{array}{l}\text { NL } \\
(\%)\end{array}$ & $\begin{array}{l}\text { PEI } \\
(\%)\end{array}$ & $\begin{array}{l}\text { NS } \\
(\%)\end{array}$ & $\begin{array}{l}\text { NB } \\
(\%)\end{array}$ & $\begin{array}{l}\text { OB } \\
(\%)\end{array}$ & $\begin{array}{l}\text { ON } \\
(\%)\end{array}$ & $\begin{array}{l}\text { MB } \\
(\%)\end{array}$ & $\begin{array}{l}\text { SK. } \\
(\%)\end{array}$ & $\begin{array}{l}A B \\
(\%)\end{array}$ & $\begin{array}{l}\text { BC } \\
(\%)\end{array}$ & $\begin{array}{l}\text { CA } \\
(\%)\end{array}$ & $\begin{array}{l}\text { CMWF } \\
\text { avg. } \\
\text { (\%) }\end{array}$ \\
\hline $\begin{array}{l}\text { Spends enough time with } \\
\text { them }\end{array}$ & 64 & 61 & 66 & 62 & $69^{*}$ & $66^{*}$ & 59 & 66 & 65 & 59 & $65^{*}$ & 61 \\
\hline $\begin{array}{l}\text { Encourages them to ask } \\
\text { questions }\end{array}$ & 43 & 51 & 53 & 51 & $57^{*}$ & $56^{*}$ & 47 & 49 & 52 & 50 & $54^{*}$ & 46 \\
\hline $\begin{array}{l}\text { Explains things in a way that } \\
\text { is easy to understand }\end{array}$ & 65 & $75^{*}$ & $75^{*}$ & 67 & $78^{*}$ & $74^{*}$ & 69 & 73 & $77^{*}$ & 69 & $74^{*}$ & 69 \\
\hline $\begin{array}{l}\text { Involves them as much as } \\
\text { they want in decisions about } \\
\text { their treatment or care }\end{array}$ & 65 & 63 & $69^{*}$ & 64 & 64 & $69^{*}$ & 61 & $69^{*}$ & $76^{*}$ & 64 & $67^{*}$ & 61 \\
\hline
\end{tabular}

\section{More Canadian Seniors Discussed Healthy Lifestyles, ButThere Is Still Room for Improvement}

The prevention aspect of chronic condition management emphasizes promoting healthy lifestyles. A small set of behavioural risk factors is responsible for most of the major chronic conditions: unhealthy diet, a sedentary lifestyle, excessive alcohol consumption and chronic stress (WHO 2005). To eliminate these behavioural risk factors, healthcare providers should engage patients in a discussion so that patients can learn about the consequences of these lifestyle factors and describe the challenges they face in making changes to them. In Canada, more seniors than the international average discussed healthy lifestyles with their regular doctors or medical staff (Table 2). However, only about half of seniors had these discussions, so there is room for more of these conversations.

TABLE 2.

Percentage of respondents who, in the past 2 years, talked to their doctor or other clinical staff at their regular place of care about healthy lifestyles

\begin{tabular}{|c|c|c|c|c|c|c|c|c|c|c|c|c|}
\hline & $\begin{array}{l}\text { NL } \\
(\%)\end{array}$ & $\begin{array}{l}\text { PEI } \\
(\%)\end{array}$ & $\begin{array}{l}\text { NS } \\
(\%)\end{array}$ & $\begin{array}{l}\text { NB } \\
(\%)\end{array}$ & $\begin{array}{l}\text { OB } \\
(\%)\end{array}$ & $\begin{array}{l}\text { ON } \\
(\%)\end{array}$ & $\begin{array}{l}\text { MB } \\
(\%)\end{array}$ & $\begin{array}{l}\text { SK. } \\
(\%)\end{array}$ & $\begin{array}{l}A B \\
(\%)\end{array}$ & $\begin{array}{l}B C \\
(\%)\end{array}$ & $\begin{array}{l}\text { CA } \\
(\%)\end{array}$ & $\begin{array}{l}\text { CMWF } \\
\text { avg. } \\
(\%)\end{array}$ \\
\hline $\begin{array}{l}\text { A healthy diet and healthy } \\
\text { eating }\end{array}$ & 38 & 40 & $53^{*}$ & 43 & 43 & $47^{*}$ & 44 & 45 & 50 & 40 & $45^{*}$ & 42 \\
\hline Exercise or physical activity & $41^{*}$ & 48 & 53 & 45 & 48 & $55^{*}$ & 56 & 51 & 55 & 53 & $52^{*}$ & 50 \\
\hline Alcohol use & $7^{*}$ & $12^{*}$ & $10^{*}$ & $11^{*}$ & $22^{*}$ & $15^{*}$ & 17 & $12^{*}$ & 21 & 16 & 17 & 18 \\
\hline $\begin{array}{l}\text { Things in their life that worry } \\
\text { them or cause stress }\end{array}$ & $12^{*}$ & 19 & 19 & 20 & 20 & 22 & 18 & 16 & 23 & 20 & 21 & 20 \\
\hline
\end{tabular}

\section{More Canadian Seniors Are "Very Confident" in Managing Their Health Problems, But There Is Room for Improvement of Care between Doctor Visits}

To ensure that patients have the confidence to manage their chronic conditions, collaboration between healthcare providers and patients needs to happen in different settings. In the doctor's office, patients need to be involved in setting treatment goals and care priorities for their conditions. These goals can then guide the development of a treatment plan that they can carry out in their lives. In addition, patients need to be given clear instructions about symptoms to watch for so they know when to seek further care. At home, healthcare providers can contact patients to ensure that they have been able to follow 
their treatment plans. Conversely, when patients have questions, they should be able to easily contact healthcare professionals to ensure that problems are addressed in a timely manner. Engaging patients in different settings will help patients gain the confidence they need to manage their health problems.
In Canada, more seniors with chronic conditions ${ }^{1}$ than the international average were "very confident" in managing their health problems and more discussed their goals and made treatment plans (Table 3). However, there is room for more proactivity by healthcare providers to engage patients between doctor visits.

TABLE 3.

Percentage of respondents with chronic conditions who are involved by their regular doctors in their chronic condition treatments.

\begin{tabular}{|c|c|c|c|c|c|c|c|c|c|c|c|c|}
\hline & $\begin{array}{l}\text { NL } \\
(\%)\end{array}$ & $\begin{array}{l}\text { PEI } \\
(\%)\end{array}$ & $\begin{array}{l}\text { NS } \\
(\%)\end{array}$ & $\begin{array}{l}\text { NB } \\
(\%)\end{array}$ & $\begin{array}{l}\text { OB } \\
(\%)\end{array}$ & $\begin{array}{l}\text { ON } \\
(\%)\end{array}$ & $\begin{array}{l}\text { MB } \\
(\%)\end{array}$ & $\begin{array}{l}\text { SK. } \\
(\%)\end{array}$ & $\begin{array}{l}A B \\
(\%)\end{array}$ & $\begin{array}{l}\text { BC } \\
(\%)\end{array}$ & $\begin{array}{l}\text { CA } \\
(\%)\end{array}$ & $\begin{array}{l}\text { CMWF } \\
\text { avg. } \\
(\%)\end{array}$ \\
\hline $\begin{array}{l}\text { Are very confident in their } \\
\text { ability to control and manage } \\
\text { their health problems }\end{array}$ & $45^{*}$ & 37 & $47^{*}$ & 40 & $23^{*}$ & $47^{*}$ & 36 & 40 & $50^{*}$ & 42 & $41^{*}$ & 35 \\
\hline $\begin{array}{l}\text { Discussed their goals } \\
\text { and care priorities with a } \\
\text { healthcare professional }\end{array}$ & 59 & 58 & $69^{*}$ & 63 & 62 & 61 & 56 & 67 & $68^{*}$ & 67 & $63^{*}$ & 60 \\
\hline $\begin{array}{l}\text { Received clear instructions } \\
\text { about symptoms to watch } \\
\text { for and when to seek further } \\
\text { care or treatment }\end{array}$ & 52 & 60 & 65 & 60 & 60 & 60 & $50^{*}$ & 59 & 58 & 60 & 59 & 59 \\
\hline $\begin{array}{l}\text { Have a treatment plan for } \\
\text { their chronic condition that } \\
\text { they can carry out in their } \\
\text { daily lives }\end{array}$ & $84^{*}$ & $78^{*}$ & $85^{*}$ & $86^{*}$ & 70 & $82^{*}$ & $83^{*}$ & $81^{*}$ & $84^{*}$ & $84^{*}$ & $80^{*}$ & 67 \\
\hline $\begin{array}{l}\text { Have a healthcare } \\
\text { professional contacting them } \\
\text { to see how things are going } \\
\text { between doctor visits }\end{array}$ & $9^{*}$ & $11^{*}$ & $12^{*}$ & 18 & $14^{*}$ & $15^{*}$ & $7^{*}$ & $10^{*}$ & 16 & 13 & $14^{*}$ & 19 \\
\hline $\begin{array}{l}\text { Have a healthcare } \\
\text { professional who they can } \\
\text { easily contact to ask a } \\
\text { question or get advice about } \\
\text { their health condition(s) } \\
\text { between doctor visits }\end{array}$ & 62 & 65 & 67 & 70 & $59^{*}$ & 66 & 59 & 62 & $76^{*}$ & 65 & $65^{*}$ & 67 \\
\hline
\end{tabular}

* Significantly different from the CMWF average

\section{Summary}

Patients play a significant role in the management of chronic conditions. In Canada, more seniors felt engaged by their regular doctors than the international average. However, fewer engaged in discussions about health promotion and chronic condition treatment than the international average. To ensure the effectiveness of chronic condition management in Canada, more patients need to be engaged in chronic condition care. $\mathrm{HQ}$

\section{Acknowledgement}

Core funding for The Commonwealth Fund's 2017 International Health Policy Survey of Seniors was provided by The Commonwealth Fund with co-funding from the following organizations outside of Canada: the New South Wales Bureau of Health Information (Australia); the Victoria Department of Health and Human Services (Australia); the Haute autorité de santé (France); the Caisse nationale de l'assurance maladie des travailleurs salariés (France); the Institute for 
Quality Assurance and Transparency in Healthcare (IQTIG) (Germany); the Scientific Institute for Quality of Healthcare, Radboud University Nijmegen (the Netherlands); the Dutch Ministry of Health, Welfare and Sport (the Netherlands); the Norwegian Knowledge Centre at the Norwegian Institute of Public Health; the Swedish Ministry of Health and Social Affairs; the Swedish Agency for Health and Care Services Analysis (Vårdanalys); the Swiss Federal Office of Public Health and other country partners.

Within Canada, funding for an expanded Canadian sample was provided by the Canadian Institute for Health Information (CIHI), the Commissaire à la santé et au bien-être du Québec and Health Quality Ontario. Additional information that highlights the Canadian story can be found online on the CIHI website. Full data sets of the survey results are available to researchers upon request at cmwf@cihi.ca.

\section{Note}

1. Chronic conditions include hypertension or high blood pressure; heart disease, including heart attack; diabetes; asthma or chronic lung disease such as chronic bronchitis, emphysema or chronic obstructive pulmonary disease; depression, anxiety or other mental health problems; cancer; joint pain or arthritis and stroke.

\section{References}

Anderson, G. 2010. Chronic Care: Making the Case for Ongoing Care. Princeton, NJ: Robert Wood Johnson Foundation.
Bodenheimer, T., E.H. Wagner, and K. Grumbach. 2002. "Improving Primary Care for Patients with Chronic Illness.” JAMA 288(14): 1775-79.

Canadian Institute for Health Information (CIHI). 2018. How Canada Compares: Results from The Commonwealth Fund's 2017 International Health Policy Survey of Seniors. Ottawa, ON: CIHI.

Coulter, A. 2012. "Patient Engagement - What Works?" Journal of Ambulatory Care Management 35(2): 80-89.

Simmons, L.A., R.Q. Wolever, E.M. Bechard and R. Snyderman. 2014. "Patient Engagement as a Risk Factor in Personalized Health Care: A Systematic Review of the Literature on Chronic Disease." Genome Medicine 6(2): 16.

World Health Organization (WHO). 2005. Chronic Diseases and Their Common Risk Factors. Retrieved April 19, 2018. <http://www.who.int/ $\mathrm{chp} /$ chronic_disease_report/media/Factsheet1.pdf>.

World Health Organization (WHO). 2017. Noncommunicable Diseases. Retrieved April 19, 2018. <http://www.who.int/mediacentre/ factsheets/fs355/en/>.

\section{About the Authors}

Grace Cheung, MSc, is a senior analyst in Health System Research at $\mathrm{ClHI}$ in Toronto, Ontario. She is responsible for performing analyses, providing methodological support to projects and writing reports.

Patricia Sidhom, MBA, is a program lead in Health System Research at $\mathrm{ClHI}$ in Toronto, Ontario. She leads and coordinates the design and development of a variety of $\mathrm{CIHI}$ 's analytical reports.

Katerina Gapanenko, $\mathrm{PhD}$, is the manager of the Health System Research team at $\mathrm{CIHI}$ in Toronto, Ontario. She oversees the development and production of a variety of $\mathrm{ClHI}$ 's analytical reports.

\title{
Join the conversation
}

y

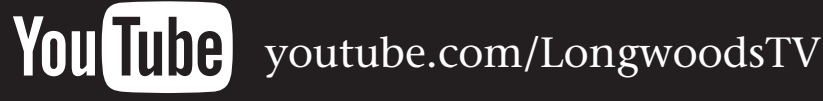

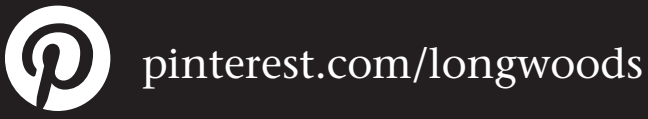

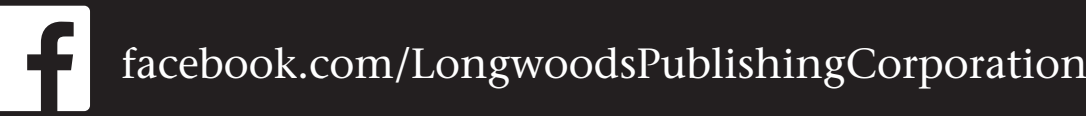

